NAGYILLÉS JÁNOS

\title{
A toledói Aloisia Sigea Szótadeus szatírája Amor és Venus titkairól
}

E sok szempontból különleges szöveg kettős hamisítvány. Igazi szerzője Nicolas Chorier (1612. szeptember 1. - 1692. augusztus 14.) francia jogász, író és történész. Egyéb nagy hatású munkái mellett ez a leghíresebb szövege. Ezt a munkáját az európai kultúrtörténet első igazán pornográf szövegeként tartják számon. Jelen fordítás a teljes szöveg bevezetője. ${ }^{1}$

Kulcsszavak: Luisa Sigea de Velasco, Aloysia Sygaea Toletana, Nicolas Chorier, Johannes Meursius, Johannes van Meurs, a pornográfia története, szatíra, irodalmi hamisítás

E sok szempontból különleges szöveg kettős hamisítvány. Igazi szerzője Nicolas Chorier (1612. szeptember 1. - 1692. augusztus 14.) francia jogász, író és történész. Egyéb nagy hatású munkái mellett ez a leghíresebb szövege. Kettős hamisítvány, mert nem a címlapon feltüntetett Sigea spanyol munkája alapján készült, és a második kiadás bevezetőjében mondottakkal ellentétben nem Meursius fordította latinra, hanem Chorier eredeti müve: Chorier a kor jeles leideni filológusa, Johannes Meursius² maszkját ölti magára, aki - állítása szerint - Sigea Aloisia de Velasco eredetileg spanyolul írt szatíráit ültette át latinra.

Chorier életrajzának fő adatai tisztázottak: Vienne-ben született, a valence-i egyetemen szerezte diplomáját 1640-ben, két évvel később megnősül és Vienne-ben működik ügyvédként 1643 és 1659 között. 1659

\footnotetext{
${ }^{1}$ A fordítás és a bevezető elkészítését az NKA az 3802/04552 számon nyilvántartott Szépirodalom és Ismeretterjesztés témakörű alkotói ösztöndíjjal támogatta.

2 Johannes Meursius (Johannes van Meurs) (1579-1639) holland klasszika-filológus és történetíró. 1610-től a leideni egyetem történelem- és görögprofesszora.
} 
végétől Grenoble-ban vásárol királyi ügyészi pozíciót. Évekkel később sikkasztással vádolják, de 1675-ben felmentik. Röviddel nyolcvanadik születésnapja előtt hunyt el Grenoble-ban, ahol egész életét töltötte. A Sigeának tulajdonított szöveg latin változatát mindössze néhány, talán barátainak szánt példányban adta ki Lyonban 1660-ban, esetleg 1661ben. A második, 1678-as kiadás címlapja nem nevezi meg a fordítót, de első szövege, Aloisia Elíziumi kertekből írt, itt közölt levele kifejti, hogy a mű egy elveszett spanyol eredeti latin fordítása, amelyet Johannes Meursius fiatal korában készített. Az elveszett eredeti szöveg nagyon gyorsan, egy hónap leforgása alatt készült, és hat szatírát tartalmazott. A latin szöveg érdekessége, hogy a narrátor az eredeti íróját, Sigeát és annak fordítóját, Meursiust éppúgy eltávolítja magától. Sigeát azért, mert a szöveg kiadásakor az Elíziumi mezőkről levelet küldő megboldogult lélek, Meursiust pedig azért, mert az Elíziumi levélbe egy teljes szatírát illeszt, és a levél végén bőszavúan dicséri Meursiust. A levelet tehát egy irodalmi formában megírt kiadói előszónak lehet tekinteni, amelyben azonban a kiadó nincs megnevezve. A könyv tehát tulajdonképpen Meursius latin fordításának kiadása, amelyben az Elíziumi levél mint kiadói előszó a soha nem létezett spanyol eredetiről közöl részleteket (egy hónap alatt készült, és hat szatírát tartalmazott).

Az 1660-as lyoni kiadás még csak hat szatírát tartalmazott (Velitatio, Tribadicon, Fabrica, Duellum, Libidines, Veneres). Az 1678-as kiadás első része (Pars prima) a következő szatírákat tartalmazza ebben a sorrendben: Velitatio, Classicum, Octavia, Duellum, Libidines - és egyre növekvő terjedelemben. A kiadás második része (Pars secunda) a már önmagában majdnem százoldalas Venerest foglalja magában. Ezután a lapszámozás újraindul, és egy Pars tertiát jelző címlap után a Fescennini következik, amely még szerepelt az első kiadásban. Ez a gyűjtemény leghosszabb, 161 oldalas szatírája. A kiadás egy Meursius-kéziratból közölt Sigealaudációval zárul, a cím alatt rövid megjegyzéssel: Nec ausim dicere deesse nihil - vagyis nem biztos, hogy a költemény szövege teljes. A második kiadás tehát egyértelmúen a szűk körnek és alacsony példányszámban kiadott első kiadás javított és bővített változataként pozicionálja önmagát, és ezt a benyomást a "kiadói narratíva” eszközeivel is támogatja: az első kiadás címlapján Meursius az eredeti spanyol szöveg fordítójaként 
szerepel, a második címlapja szerint a kiadott szöveg javított és bővített kiadás, Meursius neve és az, hogy a kiadás a spanyol eredeti fordítása egyáltalán nem szerepel rajta, ezek az adatok átkerülnek az Elíziumi levél narratívájába.

Chorier a második kiadást nyitó Elíziumi levéllel hagyja keze nyomát a kiadáson. A levélben magasztalja támogatóját, Du Guét, és két rövid saját versét is közli, amivel közvetve elismeri szerzőségét, vagy legalábbis utal rá. A hetedik szatírában továbbá a helyszín Rómából Spanyolországba kerül, és az interlocutorok, Octavia és Tullia olasz hölgyekből spanyolokká válnak.

A fordítás alapjául szolgáló szöveg az egymást követő kiadásokban bővülő corpus Isidore Lieux-féle, 1885-ös párizsi kiadásán alapul. A Lieux által gondozott szöveg bibliográfiai adatai: Aloisiae Sigeae Toletanae Satyra Sotadica De arcanis Amoris et Veneris. Aloisia Hispanice scripsit. Latinitate donavit Joannes Meursius. Re vera auctore Nicolao Chorier. Parisiis Cura et studio Isidori Liseux, editoris Rue Bonaparte, no 25. Venit apud Theophilum Belin, Bibliopolam Quai Voltaire, nº 29, 1885. 


\section{Aloisiae Sigeae Toletanae Satyra Sotadica DE ARCANIS AMORIS ET VENERIS}

Aloisia Hispanice scripsit Latinitate donavit Ioannes MEVRSIVS V.C.

\section{MONITUM LECTORI}

Vivebat ante annos centum et triginta Aloisia Sigea, Hispana, Toleti nata. Ingenio, eruditione, forma praestitit, et omnibus virtutum dotibus quae laudari solent plurimum et ingenuas maxime decent, excelluit. Sed non in abjecta et stupida animi demissione, non in sordida rei familiaris cura, non in vili nugarum studio virtutem sibi positam habebat: liberalibus navare operam disciplinis, scriptis aeternam sibi parere ${ }^{1}$ famam, ad summam sapientiam niti, non ad summas contendere opes, id demum optimum putabat et praedicabat; quod tamen pleraeque foeminae omnes per ignaviam negligunt, homines multi per socordiam stultam et furentem contemnunt. Quamobrem veri amans, libere malas insectabatur; quae sentiret, ultro faciebat palam, et velut quandam morum e curuli sella Censuram exercebat, quam suspicerent omnes, et cujus ob os ora obverterent sua. Se imprimis nobilium mulierum flagitiosis foedisque voluptatibus infensam ostendebat, et quo, injecto saltem pudore, ad meliorem revocaret frugem nihil non agebat. Pati non poterat, ut dicebat, specie praelucentes, nobilitate commendabiles, brevis gaudii aut spe aut gustu velut emotas mente, in ludibria ipsas se vertere. Addebat, ut Virtuti honestum et gloriosum est nudam sisti ob oculos mortalium, sic Vitiis esse ignominiosum. Quae meretricie viverent, ideo voluit e fornicibus suis in quibus latebant in scenam humanae vitae nudas educere, quae essent documento impune non peccari, mulieres quasdam superbi nominis et oris, et alto cretas sanguine. Nam quas Tulliam, Octaviam, Semproniam, Victoriam vocat, eae fuerunt Ducum, Marchionum, Comitum aut uxores aut natae.

\footnotetext{
${ }^{1}$ A latin szövegkiadásokkal szemben itt parere helyett parare-t olvasunk.
} 


\section{A TOLEDÓi ALOISIA SigAEA SZÓTADEUS SZATÍRÁJA AMOR ÉS VENUS TITKAIRÓL}

Aloisia spanyol könyvét latinra átültette a kiváló Ioannes Meursius

\section{Intelem az Olvasóhoz}

Aloisia Sigaea százharminc éve élt Hispániában, szülőhelye Toledo volt. Tehetsége, müveltsége és szépsége egyaránt párját ritkította, s kiemelkedett az erények minden dicsérendő nemében, de leginkább a nemes emberhez méltó erényekben. Osztályrészül kapott tehetségét nem silányította alávaló és ostoba lealacsonyodássá, s nem fordította sem családi vagyona szennyes gondjaira, sem léhaságok olcsó hajhászására - tudta és vallotta: úgy lesz a legjobb, ha a szabad tudományokkal törődik, írásaival szerez örök hírt magának, s a bölcsesség, s nem holmi pénzhegyek ormára tör. Mindez a nők legtöbbjét egytől egyig hidegen hagyja, és sok ember hány rá fittyet ostoba és eszement hanyagságból. Ez okból, mert szerette az igazságot, szabadon becsmérelhette az elvetemült nőket, gondolatait önként hozta nyilvánosságra, s mintha csak hivatali széken ülne, s mindenki rá emelné tekintetét és ajkán csüggene, tartott egyfajta erkölcsi ítéletet. Különösen a nemes hölgyek becstelen és rút gyönyöre bőszítette, és semmit el nem mulasztott volna, hogy felébressze bennük a szégyent, és újra megnyerje őket a helyénvalóbb életvitelnek. Mint mondogatta, képtelen volt elviselni, hogy e tündöklő szépségü, már csak nemesi mivoltuk miatt is jobb sorsra érdemes hölgyek eszét a rövidke gyönyör reménye vagy megízlelése elvegye és őket játékszerévé tegye. Azt is mindig hozzáfüzte: igaz, hogy tisztesség és dicsőség az Erénynek mezítelenül nyilvánulnia meg az emberi szem előtt, ám ugyanez gyalázat a Bünöknek. Csupán azért akarta a kéjnőként élő, de kéjbarlangjaikban rejtőző nőket pőrén az emberi élet színpadára állítani, hogy ők legyenek a bizonyság: büntetlenül vétkezni mégoly fennkölt nevü, dölyfös ábrázatú és magasztos származású hölgyeknek sem szabad. Így hát, akiket Tulliának, Octaviának, Semproniának és Victoriának nevez, igazából hercegek, márkik és grófok hitvesei és leányai. 
Nihil de his enarrat quod vere factum non sit, et ut erat a mendacio et ab omni dissimulationis specie alienissima, liberiori omnia sermone executa est, qui solus conveniebat. Satyram Sotadicam inscripsit opus, quod Colloquiis septem complexa est, ac Eleonorae Marguaridae Roderici marchionis uxori, sodali suae, dedicavit, qua jubente susceperat, qua urgente, ut in quadam epistola ad illam data, loquitur, intra mensem absolverat. De Sotade nihil est quod dicam; rerum amatoriarum scriptorem fuisse liberrimum fugit neminem. Sed foeminam ad scribendum his de rebus animum appulisse, non mirum videri debet: nam Elephantis puella, et aliae quaedam, hoc fuere scriptionis genere celebres. Praeterea aptiores sunt foeminae his rebus depingendis, si quae sint cordatae et non fatuae procacitatis; siquidem libidinum ipsae sunt campus in quo nascuntur omnes, in quo vigent, et, ut verbo dicam, in quo oriuntur et occidunt gaudia illecebrosa, et amoeniores joci. Forte nec tam dura fuit ut ullo nollet voluptatis sensu emollire sibi mentem ad carpenda vitae dulcia, et pars etiam puto fabularum ipsa suarum fuit non poenitenda. Hispanice scripsit; vir doctus Joannes Meursius, Lugdunensis apud Batavos Academicae lumen clarissimum, adolescens, et vix ex ephebo egressus, Latinitate donavit; etiam de suo adjecit quaedam quae Aloisiae vix persuaserim mihi venisse in mentem. Sed periit liber Aloisiae; manuscripta Meursii haec tantum lucubratio, aut si mavis commentatio, pervenit ad me: nihil ausim pro certo affirmare. Quicquid id est, non infelicis ingenii, non proletariae eruditionis partus sunt haec Colloquia, quae nec fastidium legenti creent, nec stomachum vere Sapienti moveant. Quinque priora, quae faustis avibus in manus nostras delata sunt, luci damus, quibus utique carere huic aetati bonis litteris amicae turpe esset, et studiosis arduae sapientiae durum. Duo, quae supersunt, haec aiunt longe, et arte et procacitate ingeniosa, antecellere. Sextum figuras objicit ob oculos, non tantum describit. Septimum fabellis et narratiunculis, quae ad hanc rem pertinent, mirabiliter recreat, et hoc velut cibo Attico sale condito pascit animos, cujus nulla unquam capit satietas. 
A róluk szóló elbeszélések szóról szóra megtörténtek, s minthogy lejegyzőjüktől mi sem volt idegenebb, mint a hazugság $\mathrm{s}$ a színlelés bármely neme, az egészet a szokásosnál szabadosabban adta elő, mert témájához más kifejezésmód nem is illett volna. Mưvének a Szótadeus szatíra címet adta, mert hét beszélgetést foglal magában, és barátnőjének, Rodrigo márki hitvesének ajánlotta, mert az ő kérésére fogott hozzá, és - mint egy neki címzett levelében áll - sürgetésének eleget téve egy hónapon belül be is fejezte. Szótadészről nincs mit mondanom: mindenki jól tudja, hogy szerelmi témák igen szabadszájú írója volt. Ám abban sincs semmi rendkívüli, hogy egy hölgy vállalkozott ilyesmi megírására, hiszen Elephantis és más írónők ebben a müfajban már híresek voltak. Azonkívül a hölgyek, amennyiben eszesek és nem orcátlanul ízetlenek, minden efféle ábrázolására alkalmasabbak is: ők a vágyak természetes talaja, amelyen minden vágy sarjad, amelyen elevenen tenyészik, és amelyen - kimondom kereken - a csábító örömök és érzéki élvezetek támadnak és szűnnek. Tán nem volt oly kemény, hogy ne engedte volna, hogy szíve némely élveteg érzésre mégis meglágyuljon, hogy élvezze az élet édességét, és azt is vélem, történetei egy része nem adott okot neki megbánásra. Spanyolul írt, az ifjú tudós, Joannes Meursius, a Leideni Akadémia ragyogó csillaga, alig ért férfivá, máris latinra fordította. Tett hozzá a magáéból is, de az olyan, hogy még Aloisiát is aligha győzhetném meg róla, hogy nem neki jutott eszébe. Csakhogy Aloisia könyvének nyoma veszett. Mindössze Meursius e mécsvilágnál készült kézirata, ha úgy tetszik, ujjgyakorlata jutott el hozzám, így semmit sem mernék bizton állítani. Akárhogy is, e Beszélgetések korántsem meddő tehetség vagy közönséges müveltség termékei, mert sem az olvasókban nem kelt undort, sem az igazán bölcsek gyomrát nem üli meg. Az öt elsőt adjuk közre azok közül, amelyek a szerencsének kegye folytán kezembe kerültek: ezeket szépirodalmat olyannyira kedvelő korunknak nélkülöznie gyalázat lenne, s kész kegyetlenség volna a magas bölcsesség művelőivel szemben. Ezeken fölül még kettő, úgy mondják, mind müvészi minőségével, mind szellemes merészségével kitünik. A hatodik nemcsak leírja, de szinte szemünk elé vetíti a pózokat, a hetedik pedig rövid történetekkel és elbeszélésekkel csodásan elevenít meg mindent, ami a témához tartozik, s mintegy attikai sóval ízesített étkekkel táplálja lelkünket, s lehetetlen eltelni vele. 
Et propediem juris publici fient meo itidem munere. Nam invideri tam salsa, tam lepida, tam etiam utilia bene vivendi praecepta, quis aegre molesteque non ferat saxeus et veternosus? Bonos utique mores Orator laudet Tullius; Philosophus doceat Plato: melius sane suadebunt Publius Syrus, Laberiusque Mimi. Ferit mentem et movet qui miscet utile dulci: a qua plerumque aberrat laude verbosus Orator, strigosus Philosophus. Medicamentis vires addit dum horrorem et odium adimit, qui in bellaria format solers Medicus: haec Aloisiae fuit cogitatio, et omne sibi punctum videbatur tulisse, quae tam ingeniose, tam facete utile dulci miscuisset. Vale.

De Aloisia Sigaea Toletana JOANNIS VASAEI

Hisp. Chron. Cap. 9.

\section{TESTIMONIUM}

Ut omnes alias Latinis litteris tinctas silentio praeteream, dabit Hispania Aloisiam Sigaeam Toletanam, sed in aula Lusitana per multos jam annos educatam: quinque linguarum adeo peritam, ut non immerito Paulus tertius, Pontifex Maximus, litteras illius ad se scriptas Latine, Graece, Hebraice, Syriace, atque Arabice laudibus sit prosecutus, admiratus tam multiplicem ingenii fructum, et donum tam multiplicis linguarum scientiae, in viris quoque rarum, nedum in foeminis: sic enim sonant verba Diplomatis. Debetur haec laus optimo patri, et viro doctissimo Didaco Sigaeo. Nec in ea solum hanc operam posuit, sed alteram quoque filiam Angelam, Graece, Latineque, pro aetate et sexu non mediocriter eruditam, tam exacta Musices scientia curavit perdocendam, ut vel cum praestantissimis hujus artis professoribus contendere posse putem. 
Ezek a közeljövőben jóvoltomból szintén a köz megítélése alá fognak kerülni. Ugyan ki lehet oly kőszívü vagy álomkóros, hogy rossz néven venné az ily szellemes, ily ízléses s egyúttal ily hasznos életvezetési útmutatót? Bármennyire is dicséri Tullius, a szónok a jó erkölcsöket, s tanítja a filozófus Platón, Publilius Syrus és Laberius mimusai jobban megnyernek nekik bennünket. Megrendíti s megindítja szívünket, aki ötvözi a hasznosat és édest - e dicsőségtől többnyire elesik a terjengős szónok, s a száraz filozófus is. Az ügyes orvos növeli a gyógyszer hatékonyságát, ha csemegévé alakítja az ijesztő és gyülölt orvosságot. Ez volt Aloisia elgondolása, és úgy tünik, osztatlan tetszést aratott azzal, hogy oly kifinomultan és szellemesen vegyítette a hasznosat az édessel. Ég veled!

Johannes Vasaeus (Jan van Waes):² Aloisia Sigaea

(Hisp. Chron. 9. fejezet)

TANÚSÁG

Spanyolország adja a toledói Aloisia Sigaeát, hogy a latin nyelven való írásba belemerült minden más nő mellett szó nélkül menjek el - de akkor már sok évi oktatást kapott a portugál udvarban. Úgyhogy III. Pál pápa alapos okkal halmozta el dicséreteivel neki írt latin, görög, héber, szír és arab nyelvü leveleit, és csodálta, hogy tehetsége ily sokoldalú, s ennyi nyelvet tud, ami még férfiban is ritka, nem beszélve a nőkről - ezt levele szó szerint így mondja. Ezért kiváló édesapját, a tudós Didacus Sigaeust (Diogo Sigeo) illeti a dicsőség. Ezirányú erőfeszítései nem korlátozódtak pusztán Sigaeára, hiszen másik lánya, a korához és neméhez képest szintén nem hétköznapi görög és latin müveltségű Angela esetében meg oly alapos zenemúvészeti nevelésről gondoskodott, hogy nézetem szerint a művészeti ág legkiválóbb férfi oktatóival is felveszi a versenyt.

\footnotetext{
2 Jan Was vagy Waes, Johannes Vasaeus (1511-1561) flamand humanista, tanár és történetíró.
} 


\section{SUMMO VIRO ALOISIA EX ELYSIIS HORTIS S. D.}

Vernant et florent, VIR SUMME, per anni tempestates omnes, Elysiis in campis amoeni et ridentes horti: patens felicis et uberis soli aequor adeo hortus unus est nitens et suaveolens. Non noti mortalibus generis flores, rosae et herbae spirant ambrosios odores, qui beatis Manibus tenui pro anima sunt. Laeta semper coeli facies, laetus sol, puri lucis ignes: non concreta nimbis dies, non coeno lux oblita. Qualis ipse sibi sol in se est, talis est semper et nobis, nitidus et coruscans: cum radiis continuo depluit fluxu e supero orbe delicias et festivos jocos. Patulae in lucis arbores, quas vester non insevit, non vidit Vertumnus, non longo salutant intervallo sidera, et aestus temperant. Nectare fontes scatent, et aerio fluunt melle rivi. Voluptates, sed verae, sed honestae, et verae quia honestae, aera hunc nostrum percursant innumerabiles, ut vestrum illum tenebricosum leves atomi, rerum caeca principia. His in plagis nulla a furentis libidine fortunae pendet felicitas, qui felicitatis apex est arduus verae et constantis. His vero in locis centum jam abhinc annos laetam et fortunatam laeta et beata agito vitam. Undique et undequaque delectant et juvant omnia. Sane ultra nihil esse putabam, quod irrequietae vellem mentis correpta, ut olim fiebat, vertigine concupiscere. Attamen erat. Miraberis, VIR MAGNE: tot inter gaudia Satyram Sotadicam tibi meam placuisse, et id mihi gaudium fuit longe maximum, et omnium cumulus. Esse acceptam tanto viro mihi gratulor et triumpho. Illum ingenii mei partum fovisti in sinu nudum et aegrum: paterno complectens tutatus es amore, quem videbar abjecisse et abdicasse. 


\section{Aloisia üdvözli a kiváló férfit az Elíziumi kertekből}

Tavaszi virágpompában az Elíziumi mezők kellemes, mosolygó kertjei, kiváló férfiú. Az áldott és termékeny síkság szinte egyetlen pompás és édes illatú kert. Eleven ember nem látta fajú virágok, rózsák és növények lehelnek ambróziás illatot, s az lenge szellőként legyezgeti az üdvözült lelkeket. Az ég orcája mindig boldog, boldog a nap, a tiszta fényü csillagok. A napfény elé nem tornyosul felhő, a fény mocsoktalan. A nap mindig olyan nekünk, mint önmagában és önmagának: ragyog és tündököl. A magas égből sugaraival szakadatlanul záporozza ránk a gyönyört és víg kedélyt. A ligetekben terebélyes fák, nem a ti Vertumnusotok ültette, még csak nem is látta őket, a csillagoknak közelről köszöngetnek s mérséklik a meleget. A források nektárral csörgedeznek, a patakokban a lég méze árad. Gyönyörök, de igaz és tisztes gyönyörök igaz, mert tisztes gyönyörök cikáznak számlálatlanul a mi levegőnkben, olyformán, mint a ti sötét levegőegetekben a könnyü atomok, a világ e láthatatlan alkotóelemei. Tájainkon a boldogság egyáltalán nem függ az őrjöngő szerencse kényétől-kedvétől: az igaz és tartós boldogság meredek orma ez. Már száz éve élem boldog és szerencsés életem boldogan és üdvözülten. Minden gyönyörrel és örömmel halmoz el mindenünnen. Én tényleg azt hittem, nincs annál nagyobb, mint amiért a vágy nyughatatlan szívem örvényében sodorva hajtott. De volt. Meg fogsz döbbenni, nagyszerü férfiú: még ennyi öröm közepette is messze örömeim legnagyobbika s mindjük csúcspontja az volt, hogy Szótadeus szatírám elnyerte tetszésedet. A boldogság ült diadalt szívemben egy ily nagyszerű férfi elismerésétől. Tehetségem e magzatát - még gyenge volt s mezítelen - öledben melengetted. Én látszólag elhagytam és lemondtam róla, de te atyai szeretettel magadhoz ölelted s gyámolítottad. 
ALOISIA: Confabulabamur ego, et animae magnae, Lucilius, Varro, Horatius, Ovidius, Persius, Juvenalis, Sulpicia, Petronius, Boccacius, Petrus Aretinus, Bernius, Rabelesius, Rapinus, Barclajus et Boccalinus, sub umbrosa ulmo. Nam vobis cibus sunt, quo enutriuntur corpora vestra, mortalibus far et vinum; nobis vero collocutiones immortalibus mutuae, quibus pascimur, dapes et cupediae. Maia gnatum videmus cito advolare ad nos cursu. Lectum animas venerat quibus altera, his diebus, fato corpora debebantur. Ut prope factus est, et oculos et vocem ad me convertit:

MERCURIUS: Euge, Aloisia, inquit, euge.

PETRONIUS: Atenim hanc evocas ad superas auras, interpellat commotior Petronius, quae nudiustertius huc demissa non ita longe distat a vita? Me praeteris qui mille ante annos exulo? O fatui injuriam fati!

HORATIUS: Ego vero, ait Horatius, eruditae et ingeniosae meae nugae adblandiri solitae erant maximo, qui unquam fuit, rerum moderatori: et audio in Celtico solo imperare alterum Augustum. Redde me, Mercuri, Principi meo, redde Horatium Deo suo.

\footnotetext{
${ }^{3}$ Gaius Lucilius (Kr.e. 180 után-103) római szatíraköltő, a római verses szatíra műfajának megalapítója.

${ }^{4}$ Marcus Terentius Varro (Kr.e. 116-27) római költő, író, polihisztor. 150 könyvnyi, csak töredékekből ismert menipposzi szatíra írója.

${ }^{5}$ Quintus Horatius Flaccus (Kr.e. 65-8) római költő, a római verses szatíra müfajának megújítója.

${ }^{6}$ Publius Ovidius Naso (Kr.e. 43-Kr.u. 17/18) aranykori római költő. Nem szatíraköltőként, hanem a római szerelmi elégia, illetve erótikus tanköltemények szerzőjeként szerepel.

7 Aulus Persius Flaccus (Kr.u. 34-62) a klasszikus ókori római verses szatíra időrendben harmadik legnagyobb alakja.

8 Decimus Iunius Iuvenalis (Kr.u. 60 k.-130 k.) római költő, a klasszikus római verses szatíra időrendben negyedik legnagyobb alakja.

9 Sulpicia Domitianus-korabeli római költőnő, Martialis két epigrammájából ismert, de később Ausonius, Sidonius Apollinaris és Fulgentius is említi. A ma ismert két rövid költeménye valószínűleg késő ókori hamisítvány.
} 


\section{ALOISIA ÉS MÁS SZELLEMEK BESZÉLGETÉSE AZ ALVILÁGBAN}

ALOISIA [MINT ELBESZÉLŐ]: Egyszer egy árnyas szil alatt beszélgettünk, én és olyan nagyszerü lelkek, mint Lucilius, ${ }^{4}$ Varro, ${ }^{5}$ Horatius, ${ }^{6}$ Ovidius, ${ }^{7}$ Persius,${ }^{8}$ Juvenalis, ${ }^{9}$ Sulpicia, ${ }^{10}$ Petronius, ${ }^{10}$ Boccacius, ${ }^{11}$ Petrus Aretinus, ${ }^{12}$ Bernius, ${ }^{13}$ Rabelesius, ${ }^{14}$ Rapinus, ${ }^{15}$ Barclajus ${ }^{16}$ és Boccalinus. ${ }^{17}$ Nálatok ételek táplálják a testet: a halandók tápláléka a kenyér és bor, a miénk, üdvözülteké az egymással való eszmecsere, ez minden étkünk és csemegénk. Látjuk ám, Maia fia fürgén hozzánk röppen. Látogatása célja az volt, hogy kiválassza a lelkeket, kiknek a végzet mostanában rendelt új testet felvenni. Amint közelünkbe ért, rám nézett és megszólított:

MERCURIUS: Indulás, Aloisia, indulás...

PETRONIUS: Csak nem épp ôt szólitod a felvilágra? - vágott szavába Petronius nyugtalanul. Még harmadnapja se került ide, s az élettöl sincs még elég távol. Én nem kellek, holott már vagy ezer éve vagyok számkivetésben? Jaj, mily igazságtalan a balga végzet!

HORATIUS: Nem, én következem! - szólt Horatius. Míves és szellemes csacskaságaim a valaha élt leghatalmasabb fejedelemnek voltak kedvére. S most hallom, a kelták földjén egy második Augustus uralkodik. Adj vissza, Mercurius, Fejedelmemnek, add vissza Horatiust istenének!

10 Petronius Arbiter (27?-66) Nero-korabeli római író, Satyricon című menipposi szatírájáról ismert szatíraíróként.

${ }^{11}$ Giovanni Boccaccio (1313-1375) gyakori szerelmi témái miatt kerül a beszélgetőpartnerek közé.

12 Pietro Aretino (1492-1556) itáliai reneszánsz író és költő. Érzéki szonettek szerzőjeként kerül a beszélgetőpartnerek közé.

13 Francesco Berni (1497/98-1536) itáliai költő, szatirikus költemények nagy hatású szerzője.

14 François Rabelais (1494 k. -1553) francia humanista reneszánsz író. Gargantua és Pantagruel címü szatirikus regénye folytán résztvevője a beszélgetésnek.

15 Nicolas Rapin (1535-1608) reneszánsz francia költő, fordító, egy Satire Ménippée szerzője (1593/4).

16 John Barclay (1582-1621) skót író, költő, egy több részben kiadott Satyricon szerzője.

17 Traiano Boccalini (1556-1613) reneszánsz itáliai író, politikai szatírák szerzője. 
LUCILIUS: Nam, adjicit Lucilius, magna desunt ingenia magni Principis laudi.

PERSIUS: Tu, ait Persius, secuisti, Lucili, et Mutios et Lupos, et Urbem totam. Tu vafer omne tangebas, Flacce, vitium ridenti amico, et dimissus circum praecordia ludebas. Ut ringeres, Lucili, ut obgannires, Horati! In illa Celtarum Roma scripturiunt omnes: unus aut alter scribit. Cantillant balba de nare rancidulum quid: unus aut alter heroice canit Heroi. Fugient, si velis, hi Lemures. Restituetur Musis suus honos, si nobis vita.

SULPICIA: Sed et sexus mei, subdit Sulpicia, illecebrosa amat decora; et sexui meo decus fui, et sum. Juvenem non fallit Heroa in ingenio pulchrae puellae multo majorem elucere pulchritudinis partem. Placebo, laudabit, si viderit decimam Musam. Et, si laudaverit, provocabo ad cantum novem sorores. Raucae silebunt fulgentis aulae cornices, et garrulae picae.

VARRO: In pravos aetatis meae mores, inquit Varro, Satyricam commovi bilem. Menippaeum strinxi stylum, doctissimus Romanorum. Nullius peperci vitiis, sed nullius animum laesi: arte temperavi industria acerbam medicinam, sed salubrem. O si...

ARETINUS: Plura volentem interrupit succensens Aretinus: Dum essem in humanis, ait, audiebam ${ }^{18}$ Flagellum Principum. Timuere Aretinum, qui Jovem non timebant.

BERNIUS: Apage, lavernio, refert Bernius, qui indoctis tuis et insulsis scurrilitatibus non tam notasti mores, quam corrupisti; qui, si scarabaei non nascerentur, nequidem natus esses. Ego vero Procerum ulcera acri tabo fluentia lavi aceto, sed roseo, sed odoro. Perfricui sale, sed Attico. Medicinam feci sanus. O si...

BOCCALINUS: Enimvero in nugis et tu et ille, infit Boccalinus, fuistis toti. Reges mihi et regna solerti ludus fuerunt ludenti, ut solent esse fortunae. Per me saltarunt libere, cachinnos edidere altos et sonoros, et tetricum posuere supercilium Politicae artes, et, ut loqui solebas, Persi, aerumnosi Solones. Effusi sunt et ipsi in cachinnos sonantes.

18 A latin szövegkiadásokkal ellentétben a szót audiebarra javítjuk. 
LUCILIUS: Persze - vágja rá Lucilius -, mert a nagy fejedelem dicsősége már csak nagy tehetségekre vár!

PERSIUS: Te, Lucilius - így Persius - a Mutiusokat és Lupusokat ostoroztad, és egész Rómát. Te, Flaccus, minden bünt felhánytorgattál, de ravaszul, mert barátod közben nevetett, s a szívek mélyébe bocsátkozva tréfálkoztál. Hogy vicsorognál, Lucilius, hogy csaholnál rájuk, Horatius! Ama kelta Rómában mindenkinek írhatnékja van, egyik-másik ir is. Orrukból emésztéstól büzlő dalt dudorásznak. Egyik-másik hösi dalt zeng a Hősnek. Ha akarod, megfutamodnak majd e kísértetek. A Múzsák visszakapják tiszteletüket, ha én kapom vissza az életet.

SULPICIA: Csakhogy - vág közbe Sulpicia - az én nemem megkapó ékességeit is igencsak kedveli! S nememnek én is ékessége voltam és vagyok. Az ifjú Hös nem véti el, hogy egy szép leány tehetségéból a szépség sokkal nagyobb részt ragyog elö. Tetszését el fogom nyerni, magasztal majd, ha meglátja a tizedik Múzsát. S mikor dicséretét elnyerem, kilenc nôvéremet is dalra késztetem. A fényes udvarban költögető rekedt varjakban s cserfes szarkákban benne szakad a szó.

VARRO: Szatírám epéjét - így Varro - korom fonák erkölcseire öntöttem. Róma legnagyobb tudósa voltam, s Menippus tollát rántottam ki ellenük. Bünt nem kíméltem, ám senki lelkébe nem tiportam. Müvészetem lankadatlan keverte keserü, ám üdvös gyógyszerét. Ó, ha...

ARETINUS: S még folytatta volna, ha dühösen közbe nem vág Aretinus: - Míg emberek közt éltem - mondta -, a Fejedelmek Ostorának hívtak. Jupitertól nem féltek, de Aretinótól igen.

BERNIUS: Eridj már, te Laverna fattya! - így Bernius. - Ostoba és ízetlen bohóckodásoddal nem megbélyegezted, hanem magad rontottad meg az erkölcsöket. Meg se születtél volna, ha nem teremne ganajtúró a földön! Én viszont az előkelők fekélyeit maró gennyel mostam, ám az rózsás és illatos volt. Sót dörzsöltem rájuk, de attikai sót. Orvosságot készítettem, mert egészséges voltam. Ó, ha...

BOCCALINUS: Márpedig te is meg amaz is léha senkik voltatok - veszi át a szót Boccalinus - a fejetek búbjáig. Én viszont királyokkal és országokkal üztem szellemes játékot, ahogy a szerencse szokta. Jóvoltomból dévajul táncoltak, gyöngyözö kacajuk az égig hatolt, a politika tudománya s a - mint mondani szoktad, Persius - bús Szolónok leengedték pökhendi szemöldöküket. Maguk is csengő kacajjá oszlottak. 
RAPINUS: Cui non lecta Satyra Menippoea mea? reponit Rapinus. Cui non placuit? Malae causae dum personam detraho, qua superbiebat, bonae opi fui. Novum instruxit Minerva mea armamentarium pugnanti Marti Gallico. Ex hoc sumpsit tela, quibus perduellium prosterneret animos, ut pectora et urbes aliis perfringebat fulminans Heros.

MERCURIUS: Atenim quid vobis vultis, cari Manes? infit Mercurius indignans. Exspectatis compescam ego motus hos insanos delinificae virgae minis? Nam evocat Jupiter Alexandrum Macedonem et Machiavellum Florentinum, nescio quid magni parans. Omnia scilicet in terris improba et felici ille temeritate, dolis hic malis et caecis artibus susque deque miscebunt, furentes una et fallentes. Non eo sunt in statu res humanae, cui pro merito debeatur Horatius aut Varro. Toti sunt qui laudantur in gerris; toti in fabulis qui ingeniosi audiunt, et ipsi AEsopicae fabulae loquentium et disserentium bestiarum. Qui lucubrationum laude praedicantur, striges sunt. Florere jactitant per se ambitiosi ingenuas disciplinas; marcescunt excisae. Se tamen amant homines nihili, invicem se mirantur: muli mulos alternis scabunt. Videntur sibi esse belli (loqui sic solebas, Varro), festivi, saperdae, cum sint Kár $\rho \circ$. Iniqui judices, nihil habent in pretio praeter somnia sua nullius pretii. Tibi tamen, Aloisia, nulla irascitur in terris livoris malignitas. Satyrae Sotadicae qui plausus negant, blando favent murmure. Eruditi osculantur, boni gaudent, quod demum inveneris viam floribus consitam, qua iretur ad virtutem. Nam mira opifex libero sermone bonos optime condoces mores, et malis suades exemplis; obliqua ad honestatem ducis via ingenuo delinitas ludo mentes. Non ocius alii recta irent. Compendiaria haec est.

ALOISIA: Id mihi quidem, cum animum ad scribendum appuli, respondeo, fuit, Mercuri, propositum. Produxi ab intimis Amoris et Veneris arcanis, quos libido fervens infundit furores insanientibus malis. Palam feci quae fieri solent stulta et foeda, hoc ut spectaculo a faciendo deterrerem quibus honor curae esset, pudorem libidinosis injicerem, odium libidinum incuterem. 
RAPINUS: De volt-e, aki nem olvasta az én Menipposi Szatírámat? - szólt közbe Rapinus. Amikor lerántom a gonoszság maszkját, amelyben pöffeszkedett, a jó ügyet szolgálom. Minervám a galliai harchoz új fegyvertárral szerelt fel. Innen vette a harcolók lelkeit ledöfó lándzsákat, míg a villámot szóró Hös a szíveket s városokat másokkal zúzta össze.

MERCURIUS: Tulajdonképpen mit akartok, kedves Szellemek? - bosszankodik Mercurius. Azt várjátok, hogy én béklyózzam meg enyhülést szerző pálcámmal fenyegetózve az esztelen indulatokat? Hisz Jupiter most Nagy Sándort és a firenzei Macchiavellit szólitja: valami nagy terve lehet. Ami gazság csak létezik a világon, ezek ketten - egyikük szerencse kegyelte vakmeröségével, a másikuk rosszhiszemü cselekkel és fölfedhetetlen trükkökkel, ám egyszerre örjöngve és másokat ámítva-kavarják össze-vissza. A kialakult helyzetben szinte nem történik semmi a társadalomban, ami ne kiáltana teljes joggal Horatiusért vagy Varróért. Mindazok, akiket magasztalnak, csupa semmiséggel foglalkoznak, mindazok, akikröl a mesékben leleményességük miatt hallunk, maguk sem többek, mint az aesopusi mesék beszélő és gondolkodó állatai. Akiket virrasztásukért magasztalnak, baglyok. Magukban hencegnek nemes tudományukkal a becsvágyók, s ha elmetszik szárukat, elfonnyadnak. A semmirekellök mégis odáig vannak maguktól, s csodálja egyik a másikát: felváltva vakarja egyik öszvér a másikat. Szépnek, csinosnak és bölcsnek látják magukat (így szoktad mondani, Varro), pedig vaddisznók. Igazságtalan birák, értéket semmiben sem látnak, csak saját hitvány álmodozásukban. De nincs irigy rosszindulat az árnyékvilágon, amely rád haragudnék, Aloisia. Ha nem is harsan tapsvihar Szótadeus szatírádra, kegyeli a helyeslő suttogás. A müveltek keblükre ölelik, a derekak öröme kíséri, hogy végre rátaláltál az erényre vezetó, virágokkal végigültetett útra. Csodás alkotó vagy, ki a jó erkölcsre fesztelen stílusodban legjobban tanítasz, s tanáccsal látsz el a rossz példák ellen, szellemes játékoddal a szíveket mellékúton terelgeted a tisztességre. Mások egyenesen sem jutnak el hamarabb odáig. Ez hát a rövidebb.

ALOISIA: Valóban ez volt a szándékom, Mercurius, mikor tollat ragadtam. - válaszoltam. Amor és Venus legmélyebb titkaiból közszemlére tettem mindama dühöt, amit a lobogó kéjvágy tölt örjöngő elvetemültekbe. Bemutattam, ami ocsmányság és dôreség csak történni szokott, hogy látványával visszarettentsem megtételétől, akibe szorult némi tisztesség, hogy kéjvágyókban szemérmet támasszak, s utálatot ojtsak beléjük a vágy iránt. 
Non sum, ut alii bene multi, excogitando assecuta quae contaminatos et temulentos fieri possent inter amantes. Quae vere facta nossem, scripto mandavi. Quasi per pompam traduxi spurca ludibria. Ope mea, forti et fideli, de scelerata Venere triumphanti virtuti ferculum id fuit opimum. Nam proba fuit vita et pudici mihi mores. Scis, Mercuri.

MERCURIUS: Scio, respondet.

OMNES MANES: Et nos omnes pariter scimus, succinunt stridulo tinnitu circumvolitantes Manes.

ARETINUS: Nec, per hanc barbam meam! me fallit. Dicens, barbam longam, hircinam Aretinus laeva mulcebat. Egregiis famam compararas tibi studiis incredibilis honestatis. Lusitanorum Regi praestans de te erat opinio, adeoque Italiae toti, et terrarum capiti Romae. Audieram de tuis Colloquiis.

MERCURIUS: Tacere jussit Mercurius: Noli, inquit, laudare virginem, leno! Operam non dabas instituendis bonis moribus: opus difficile, nec tuum. Probrosas scurrilium facetiarum ineptias venditabas Osco sermone. Ingeniose desipiebas balatro amens. Meliores habet Aloisia laudatores. Nam tuis habent in Colloquiis, Aloisia, Italae et Gallicae Musae, quos non habent in suis cum Apolline, meros Nectaris succos. Te eruditi et ingeniosi trans et cis Alpes suam volunt, amant et colunt:

Te legit omnis ibi juvenisque, senexque, puerque.

Verum tibi sit unus pro omnibus. Procum habes, cujus sit amor vel praestantissimae virtuti pro praestantissima laude. Placet sibi in tuis scriptis ut in dulcissima voluptate. Excellit ingenio, excellit et dignitate. Sinceriorem certe non viderunt Celticae stellae. Splendidis cumulatiorem dotibus non habet Sequana fluviorum princeps.

SULPICIA: Erat mihi patronus in aula Domitiani, reponit Sulpicia, Plinius Secundus, vir in aetate corruptissima integerrimus, cum canerem: 
Fikcióm korántsem jutott odáig, ameddig a bujakóros, kótyagos szeretók szoktak - bár, ha tudomásomra jutott volna teljes valójában, papirra vetettem volna. Mintegy ünnepi menetben vonultattam fel kéjes malackodásaikat. Hathatós és hü segedelmemmel csak úgy roskadozott a bünös Venus felett triumfáló erény diadalszekere. Mert életem tisztes volt s erkölcseim kipróbáltak. Neked tudnod kell, Mercurius.

MERCURIUS: Igen, tudom. - felelte.

A SZELLEMEK EGYSZERRE: S mi mindannyian éppoly jól tudjuk. - harsan rá kórusban a körötte röpködő Szellemek süvöltése.

ARETINUS: A szakállamra, engem akkor sem ver át! - mondta Aretinus, s baljával hosszú, borzas szakállát simogatta. Párját ritkitó tudásod ésszel felfoghatatlan fokú megbecsültséged hirét keltette. A portugál király kitünő véleménnyel volt rólad, sôt egész Itália s az egész világ feje, Róma is. Régebben hallottam Beszélgetéseidről.

MERCURIUS: Mercurius beléfojtotta a szót: - Te csak ne dicsérgesd e hölgyet, te kurvapecér! Te fittyet hánytál a jó erkölcs megteremtésére: nehéz dolog ez, s nem neked való. Te oszkul árulgattad hírhedt és sületlen bohóctréfáidat. Elméncségeid szellemesek voltak, de kotyogó féleszü voltál. Aloisiát náladnál jobbak magasztalják. Mert a te Beszélgetéseidben, Aloisia, Itália és Gallia Múzsái olyan színnektárt kapnak, amilyet övéik közt Apolló társaságában sem. A müveltek s tehetségesek világa az Alpokon innen s túl magáénak akar, szeret és tisztel:

Falja betüid az ifjú mind, meg a vén meg a gyermek. ${ }^{19}$

Ám legyen neked csak egy mind helyett. Van egy kéröd, akinek szerelme mégoly kiemelkedő erényednek is kiemelkedő dicsőségére szolgál. Írásaidban mintegy a legédesebb gyönyör közepette gyönyörködik magában. Tehetsége páratlan, méltósága is páratlan. Nála becsületesebb nem termett még a kelta ég alatt. A folyamok királynóje, a Szajna mellett nincs, ki ennyire el lenne halmozva ragyogó adományokkal.

SULPICIA: Patrónusom volt Domitianus udvarában - vágta rá Sulpicia Plinius Secundus, a legromlottabb idók legfeddhetetlenebb embere, midőn így szólt versem:

19 A másképpen nem jelölt verssorok a szerzőtől származnak, s ha nincs más fordító megjelölve, azok a szöveg fordítójának fordításai. 
Dic mihi, Calliope, quidnam pater ille Deorum

Cogitat? An terras et patria saecula mutat?

Quasque dedit quondam morientibus eripit artes?

Indignationem meam autoritate armavit sua vir sanctus. Illo ducente invenit delitescentem, cum Caleno meo, me gloria, sub injustitia et inclementia vecordis saeculi. Et obstetricatus est Valerius Martialis nascenti famae.

OVIDIUS: Solus nemo unquam aperuit sibi, infit Ovidius, honoris difficilem aditum. Facilius multo est et proclivius laudem promereri, et laude dignum videri, quam laudari. Me Fabius Maximus, Romanae gloria prima togae, Augusto familiaris, habuit familiarem. Maximo commendante, non ausus est perstrepere raucus livor. Sidera nosse et syrtes, et navigationis callere artem, id haudquaquam navigantibus satis est, ni adspiraverit velis favens aura. Ita nec pergentibus ad gloriam bonae sufficiant artes, non ingenium, non eruditio, ni etiam opportuno impulerit flatu cymbam favens aura.

ALOISIA: Fateor, aio ego, parum mihi meriti, at famae multum fuit. Gratiae multum fuit apud optimum quemque. Nascenti nimirum risit stella tua, Mercuri. Si placui et vigui, tuum est. Sed amabo, perge dicere, care Mercuri, de illo nominis mei patrono, et commentationum tutore.

MERCURIUS: Pergam, reponit, et suave erit. Vis primum dicam de fortunae bonis? Natus est clara et nobili stirpe in magnis opibus, et Leucotetiae, quae mater urbium, ut loquitur Ammianus. Vis de animi bonis? Suae solus genti sit ipse satis ornamenti, vel deessent caetera ornamenta omnia quae abundant. Nam, ab ineunte aetate, liberalibus singularem dedit operam disciplinis, acie pollens ingenii et proba solertia. Buleutis Celticis adscitus adolescens, civium salute, honore et fortunis habuit nihil antiquius. Nullus gratiae in judiciis apud illum locus, nullus odio, nullus saevienti irae. Sunt qui alteri non gauderent bene fecisse, nisi se scirent alteri male fecisse. 
Mondd meg, Calliopé, hogy az Istenek atyja ugyan mily Tervet sző? A világot, az emberi fajt lecseréli?

Adta, $\mathrm{s}$ a müvészettől most megfosztja az embert?20

Méltatlankodásomat e szent férfiú tekintélye fegyverezte fel. Vezetése alatt talált rám a dicsőség az örült század kíméletlen igazságtalanságának mélyén Calenusommal megosztott rejtekemben. S Valerius Martialis bábáskodott születó hírem fölött.

OVIDIUS: Egy szál magában soha senki sem tárta még ki magának az elismerés nehéz kapuját. - veti közbe Ovidius. Sokkal könnyebb és egyszerübb jogot formálni és méltónak tetszeni a dicsőségre, mint azt el is nyerni. Én, Augustus barátja, Fabius Maximus, a római tóga legfőbb dicsősége köréhez tartoztam. Míg Maximus mellettem állt, a káráló irigység nem mert zúgolódni ellenem. Bármennyire ismeri a csillagokat és zátonyokat, s bárhogy ért a hajózáshoz, aligha elég a hajósnak, ha vitorláját nem dagasztja kedvezô szél. Ugyanígy, ha a dicsőség felé tartasz, ahhoz sem elég sem erény, sem tehetség, sem képzettség, ha sajkádat meg nem taszítja a kedvező szellö segítố fuvallata.

ALOISIA: Bevallom - mondom erre -, kevés érdememhez képest hírem nagy volt. S épp a legjobbnál álltam nagy kegyben. Nincs kétségem: születésemkor a te csillagod ragyogott rám, Mercurius. Ha tetszést arattam és felvirágoztam, a te érdemed. De kérlek, kedves Mercurius, most beszélj tovább arról, aki nevemet hírre segítette s tanulmányaimat támogatta.

MERCURIUS: Folytatom - mondta ő -, s gyönyörködtető lesz. Szeretnéd, ha kezdetnek a szerencse által adott javakról beszélnék? Híres és dicső nemzetségból s nagy gazdagságba született, mégpedig Leucotetiában, Ammianus szavaival a városok anyjában. Szeretnéd, ha szólnék lelki adományairól? Családja díszéül egymaga is böven elég lenne, még ha nem lennének is más díszei, pedig bövelkedik bennük. Mert zsenge gyermekkorától nem volt párja a szabad emberhez méltó tudományokban, esze pengeéles, okossága hibátlan. Már ifjan a kelták tanácsának tagjai közé választották, polgártársai üdvénél, tisztességénél és vagyonánál nem volt számára semmi fontosabb. Ítéleteire nem gyakorolt hatást sem baráti érzület, sem gyülölet, sem tomboló harag. Van, aki csak úgy örül jótettének, ha tudja, valaki másnak kárt okoz vele.

${ }^{20}$ Epigrammata Bobiensia 37, 12-14. 
Scopus est illis male facere, et interdum ad scopum via bene facere. Qualem optaret sibi aeterni numinis mentem, talis illi mens erga reliquos homines. Sic aliis Deus erat hominibus homo, ut bene multi his constituti in dignitatibus, aut praedae aut sanguinis avidi, videntur lupi, prostituta ad infamiam fama. Ad sublimiores promotus honorum gradus, animum non mutavit. Nunc adsidet Buleuta Regi, Regum Celtico Jovi. Igitur, difficillimis admotus negotiis, visus est major. Gloriosum est quam plurimis honorum luce fulgentibus, non omnino negotiis esse impares: huic, invenisse nulla quae ingenio usu rerum confirmato et politicae dexteritati paria essent.

Patrono huic tuo, Aloisia, in proclivi expedita et aperta sunt, quae aliis plerisque in arduo, obscura et impedita, pecudibus superbis. Descenditur illi ad res difficiliores genii praestantia, ut aliis, nitenti gressu, adscendendum opacitate ingenii. Nec supercilio terrorem incutit adeuntibus, nec inani insultat fastu trepidis. Vere homo, hominibus se praestat humanum. Nam qui, praeter se, nihil amant, nihil aestimant, belluas dixeris, non homines. Oblitus humanitatem jam bellua est, quandoquidem hominem exuit. Non vultus, sed mores faciunt hominem. Credulos et fidentes non ludit verborum praestigiis, non conjicit adulans in errorem. Pereant, pereant fraudum improbi artifices! Osculis petunt, quos et insidiis petunt. Amplectuntur, laudant, quibus perniciem moliuntur. Mens huic viro, ut frons, aperta. Suis de rebus nihil vult latere securus et constans, praeter benefacta. Ostendit se factis, non verbis ostentat, inanique simulatione. At enim optantem et allaborantem suis finxere manibus Virtutes et Musae. Instillarunt affectus, quos non puderet Virtutes et Musas suos fateri et agnoscere. Subcisivas non corrupit horas turpi otio. Sane quae libidinibus et nugis pars vitae datur, de vita expungitur; vitae perit. Accersit ad se amicas Musas. Conveniunt: laeta et beata cum iis ducit commercia. Hoc coelos et terras auspicio peragrat, philosophico pernix volatu. Omnia aetatum et temporum indefessus pervolat animo intervalla, historiae fido ductu. 
Az ilyenek célja a gonosztett, legföljebb néha jót is tesznek a célhoz vezetö úton. Ố úgy viszonyult a többi emberhez, ahogyan szerette volna, hogy az örök Isten viszonyulna őhozzá. Míg egyes emberek Istene a másik ember, e méltóságok viselöi közül igen sokan vagy zsákmány, vagy vér után áhítoznak, farkasnak tetszenek, s hírükön bármikor folt eshet. Rajta viszont mit sem változtatott, hogy egyre magasabbra jutott. Most a Király, a Királyok kelta Jupitere tanácsadója. Tehát nagyobbnak tetszett, mikor igen fáradságos úton idáig jutott. $\mathrm{Ha}$ számtalan megtiszteltetés fénye ragyog be valakit, dicséretére válik, ha a rábizott feladatokkal minél kevésbé küszködik - ám neki az válik dicsére, hogy nem talált még olyat, ami meghaladta volna tehetségét vagy politikai ügyességét, mikor kiderült, miként tudja használni.

Ami más embernek többnyire hozzáférhetetlen, átláthatatlan és bajos - ám ők pökhendi barmok, Aloisia -, könnyü és akadálytalanul kivihető kiváló patrónusodnak. A nehezebb ügyekhez kiemelkedő szelleme jóvoltából fér hozzá, míg másoknak tapogatózó léptekkel kell odajutniuk, mert tehetségük nem világítja meg útjukat. A hozzá folyamodókat gögje nem riasztja el, mikor amúgy is rettegnek, hiú kevélységböl nem üz gúnyt belölük. Igaz ember, emberséggel fordul az emberekhez. Akik magukon kívül senkit sem szeretnek és becsülnek, az állaton kívül mi más névvel illethetjük? Aki emberi mivoltáról megfeledkezik, máris állat, hiszen ember mivoltából vetkezik ki. Hiszékenyekböl és vakon hívőkből sem üz csúfot csalárd beszéddel, s hízelgő sem tévesztheti meg. Vesszenek, vesszenek a gaz csalók! Csókolnak, majd tört vetnek. Ölelgetnek, magasztalnak, pedig veszteden munkálkodnak. Ennek a férfinak szíve is, tekintete is nyilt. Nincs benne félelem és állhatatos, így nem rejteget semmit, csak a jótetteit. Tetteivel mutatja meg, kicsoda, nem tetszeleg szavaiban s hiú tettetésben. Mert óhaja volt és tett is érte, az Erények és Múzsák saját kezúleg formálták. Olyan hajlamokat csepegtettek bele, amelyeket, épp mert ők az Erények és Múzsák, nem kell restellniük tőlük valónak vallani és elismerni. Fölös óráit sem fecsérelte erkölcstelen idötöltésekre. Csakugyan úgy van: az életnek az a része, amelyet kéjes kedvtelésekre forditunk, törlődik belóle, elvész az élet számára. Baráti társaságba ô a Múzsákat hívja. S ốk összegyülnek nála, s élvezi derüs és boldog társaságukat. Felhatalmazásukkal a filozófia szárnyán suhanva jár be eget-földet. Lelkében fáradhatatlanul szárnyal korok és idók térségein, hü vezetôje a történettudomány. 
Sic hac in nostra natus, per omnes unus vivit aetates: sic quos oculis non vidit, celebres laude heroas habet in familiarium numero. Miscet et cantus cum Pegasidibus puellis. Lepida erudito ore fundit carmina, respondent alternis Musae. Nugae etiam illi, nec nugae sunt. Boni igitur omnes amant, cui nihil nisi boni et honesti cordi est. Colunt et praedicant uno consensu, uno concentu Leucotetii, Unelli, Ergosiavi, et Alpini Ariobriges. Humaniorem hactenus non viderant, nec commodis suis opportuniorem. Hunc ad se missum esse virum, quem a vera honoris via nulla averterit unquam lucri fames, nulla pravi affectus insania, gaudent, sed puro, sed sincero gaudio.

Gratuleris et tibi, Aule Persi: obvolvisti ipse te caeca nocte: videri nolebas. Altam versibus et versuum sensibus superfudisti caliginem. Nolebas intelligi, forte et tu non intelligebas. Non fecerunt venientem ad te nox et caligo, ut exerraret. Venit: discussit noctem et caliginem. Te proxime videt. Perspectum id omne habet, ut tute loqueris,

Quod latet arcana non enarrabile fibra. ${ }^{21}$

Eripuit tibi te neganti conspectum. Latebas intra te, ne te curiosa et erudita inveniret sagacitas. Eras ipse involucrum tibi. Quis vero fuit furor ille tuus?

ALOISIA: Nulla, exclamo ego, deleat unquam Maecenatis mei memoriam oblivio! Supremus sit illi dies qui soli erit et coelis!

PERSIUS: Vivat tanti viri nomen, subjicit Persius, in ea luce quam fugi! Effundat id in caput suos omnes gloria immortalis radios! Obsolescat nunquam celsae virtutis honos! Favet virtuti: faveant et illi virtutes! referant laudantes et plaudentes gratias quas habent!

MERCURIUS: Subridet Mercurius et caduceum movet: Audite, pii Manes, inquit. Diuturnior est vita quae suis cuique venit a benefactis: nam et verior est. Non ita diuturna quae venit a parentibus. Jupiter rerum arbiter, cujus

${ }^{21}$ Pers. 5, 29. 
Így aztán, bár a mi korunkban született, mégis egymagában megél minden eddigi kort, s így baráti körébe tartoznak mindama dicső hírü hősök, akiket saját szemével nem is láthatott. Éneke a Pegasus forrása leányaiéval vegyül. Képzett ajkairól csak úgy árad a bájos dal, felelgetnek rá a Múzsák. Még pajkos versei is rá vallanak, s igazából nem is pajkosak. Így hát minden derék ember kedveli, mert nem fekszik más a szivén, csak a jó és tisztességes. Teljes egyetértésben és teljes összhangban tisztelik s magasztalják Leucotetiában, az unellusok, Ergosia, $s$ az ariobrixek az Alpokban. Nála müveltebbet mindeddig nem láttak, s olyat sem, kinek adottságai több hasznot hajtottak volna. Örvendenek, mégpedig tiszta és ôszinte örömmel, hogy elküldték hozzájuk e férfit, akit a tisztesség igaz útjáról sem a haszonvágy, sem bármilyen fonák hajlamú esztelenség soha le nem térített.

Légy elégedett magaddal te is, Aulus Persius: magad burkolóztál sötét éjszakába: nem akartad, hogy lássanak, soraid és soraid értelmének mély homályába vontad magad. Nem akartad, hogy értsenek - bár tán magad sem értetted magadat. Az éji homály nem engedte, hogy a hozzád jutó kitaláljon belóle. S akkor jött ô és szétoszlatta az éji homályt. Közvetlen közelröl lát téged. S megérti mindazt, hogy bizton mondhasd:

azt, ami mondatlan szunnyad lelkemnek a mélyén. ${ }^{22}$

Bármennyire tiltakoztál, kicsikarta tóled, hogy láthasson. Mélyen rejtöztél önmagadban, s bárminö kíváncsi és müvelt volt is egy-egy éles elme, nem találhatott rád. Magad voltál önmagad leple. Mi volt benned e szenvedély?

ALOISIA: Erre így kiáltok fel: Nincs feledés, amely Maecenasom emlékezetét eltörölhetné! Végnapja legyen, amely a Napnak és égnek is végnapul adatott! PERSIUS: Éljen a nagyszerú férfiú emléke - mondja erre Persius - ama fényben, amelyet magam kerültem. Pazarolja ama före összes sugarát a halhatatlan dicsőség! Maradjon fenn örökké a nemes erény megbecsülése! Barátja az erénynek, legyenek hát az erények is az ő barátai. Magasztalás és taps közepette nyilvánítsanak neki hálát!

MERCURIUS: Mercurius elmosolyodik, és suhint egyet pálcájával. Hallgassatok meg, jámbor szellemek! - szól. Maradandóbb az az élet, amely kinek-kinek jótetteiből fakad, mivelhogy igazabb. Amit a szülőktól kapunk, nem oly maradandó. Jupiter a világ itélóbirája, ha ô szól

22 Muraközy Gyula fordítása. 
Pondus adest verbis, et vocem fata sequuntur, duris hanc statuit Parcarum legibus legem:

corpora quidem dedant neci; gloriam et laudem letho eximant. Instabili non subest rerum mutationi virtus, nec virtutis merces.

ALOISIA: Cum diceret, perculit aures dissipatus longe rumor, et confusae convenientium voces.

MERCURIUS: Ecce, ecce, pergit dicere Mercurius, venit ad vos humanitate clarus in Musas, ortu clarissimus, Furbinus Oppedius. Eruditionem, florens dum manebat vita, maximum duxit esse mortalium bonum Oppedius. Principem debet inter vos locum tenere. Ingenuis favit disciplinis, ex animo favit, apud leves et turbidos Salyes togae princeps. Sed enim et acceptissima fuisti Oppedio, Aloisia.

FURBINUS OPPEDIUS: Audiit ille: Libros bono numero collegi, reponit. Et in tuis, Aloisia, scriptis magna cum voluptate conquiescebam. Eruditos, quotquot voluere, in clientelam et fidem meam suscepi: suscipite et vos, pii Manes, in fidem vestram me. Sed te, Aloisia, commendarat mihi tum adprobantis testimonium famae, quum hominum ingeniosorum et doctorum de te judicium. Eras mihi amoenum et florens diverticulum a politicis curis.

ALOISIA: Raros esse, respondeo, altero sub coelo, Barclajus et Boccalinus conqueruntur, qui sui putent esse pensi in lucentibus dignitatum positi gradibus, litteris et litteratis fera subigere invidiae odia. Laetor igitur vehementer, nove hospes, meum tibi quicquam dulce et gratum tanto viro fuisse.

BARCLAJUS: Et jure conquerimur, refert Barclajus. Enimvero mihi multa intercedebat cum Peyreskio amoris necessitudo. Meis delectabatur commentationibus et moribus. At plurimum Argenidis oblectabatur historia. Commendavi regiam virginem longe commendatissimo in litterarum Republica viro. Edit ille in lucem, vult vivere nobilem ingenii mei partum. 
Súlyos minden szó, s hallgat hangjára a végzet, s szabta a Párkáknak szigorú törvényül e törvényt:

a testet adják a halálnak, ám a dicsőséget és hírnevet ragadják ki az enyészetböl. Sem az erény, sem az erény bére nincs alávetve a világ állhatatlan változásának. ALOISIA [MINT ELBESZÉLŐ]: Míg beszélt, fülünket távoli zsivaly ütötte meg, és gyülekezők összefolyó szavai.

MERCURIUS: Lám-lám - folytatja beszédét Mercurius -, a Múzsák iránti szívélyességéról híres Furbinus Oppedius érkezik hozzátok. Oppedius, míg élt és virágzott, a müveltséget tartotta az ember legfóbb javának. Vezető helyet kell köztetek kapnia. A nemes tudományok híve volt, mégpedig elkötelezett híve, első polgár az állhatatlan és heves salyes nép körében. És még ez az Oppedius is feltétel nélkül elfogadott téged, Aloisia.

FURBINUS OPPEDIUS: Ezt már ő is hallotta és így felelt rá: Jó néhány könyvet összegyüjtöttem, s a te írásaidban nagy gyönyörrel leltem megnyugvást. Akárhány müvelt fó akarta, mind pártfogoltjaim közé s bizalmamba fogadtam. Fogadjátok ti is, jámbor Szellemek, bizalmatokba. Ami téged illet, Aloisia, híred elismertségének tanúsága s müvelt és tudós emberek rólad alkotott véleménye is figyelmembe ajánlott. Kies, virágpompás menedékem voltál a politika okozta gondoktól.

ALOISIA: Erre így felelek: Barclajus és Boccalinus panaszolja, hogy más égöv alatt ritkán akad, aki a méltóságok fényes grádicsain feladatának ismerné, hogy megbéklyózza az irodalom és az irodalmárok iránti irigység okozta gyülöletet. Nagy örömömre szolgál hát, új vendég, ha bármely müvem ily jelentôs férfiú tetszését s kegyét nyerte el.

BARCLAJUS: És joggal is panaszkodunk. - szól Barclajus. - Jómagam Peyreskius ${ }^{23}$ közeli barátja voltam. Írásaim és jellemem egyaránt elbüvölték. Ám leginkább az Argenis története nyügözte le. A királyi hajadont az irodalmi köztársaság messze legközkedveltebb tagja figyelmébe ajánlottam. Ki is adta, az volt szándéka, hogy szellemem legnemesebb szülöttje továbbéljen.

${ }^{23}$ Valószínűleg Nicolas-Claude Fabri de Peiresc (1580-1637) francia asztonómus, antikvárius, tudós. Úttörő geográfiai és csillagászati kutatásai mellett (a Hold egy krátere és egy aszteroida az ő nevét viseli) De virtutibus et vitiis címü kivonata volt a korban közismert. 
Vide temporum iniquitatem, summe Furbine; hominum malignam vide stoliditatem. Non placuit varicosis Magnatum ingeniis liberalis Argenidis forma: non placebat stola Romana. Non amarunt in Latio natam pulchritudinem. Bibliopola magno, quod sumptus quos fecerat in ornanda et comenda, nullus inveniretur emptor qui refunderet, succensebat pudore offusae. Piper et thus minabatur. Erat Argenis toga cordyllis et paenula olivis futura, ni Marcassi opem obtestaretur, non magni viri, non ingenio sublimis, non doctrina locupletis. Commendavit litteratorum plebi plebeius, nec nobilis scriptor. Rem ridiculam! Principibus viris placuit Argenis, postquam ineptis et fatuis placuisset. Quos graves putant et summos esse viros, interdum noxae sunt viles et stulti. Si nudos, detracta opinionis larva, contempleris, homines non credes; aut nihili homines credes.

FURBINUS OPPEDIUS: Melius tecum, Aloisia, inquit Oppedius, fatui actum benevolentia fati. Nam inepti et ignavi illaudatam reliquerunt: magnae et excellentes mentes laudarunt, foverunt. Sunt immo qui ex animo amant, et tamen obloquuntur. Secum ipse laudat Tubero: vafer, vappa, in perniciem famae suae et bonorum ingeniosus, qui et fruitur Dis iratis, Tubero. Coram et palam illaudatam temnit. Bene sensit et male dicit, simulator improbus. Sed non tulit impune.

MERCURIUS: Feriit indignans aether sacro fulgure vanum et perfidiosum caput, inquit Mercurius. Ignominia merserunt nequam nebulonem ulciscentes Musae. Adfui nascenti Tuberoni, adjicit, cum Laverna et Cotytto; et cum poenas dedit, adfui exsultabundus: colaphos ipse impegi.

FURBINUS OPPEDIUS: Magni sane viri, sublimes animae, refert Oppedius, ut viderunt, laudibus cumularunt: deperiere. 
Gondolj bele, nagyszerü Furbinus, ${ }^{24}$ milyen ellenséges időket élünk, gondolj bele, milyen rosszindulatúak és ostobák az emberek. A nagyságok nyavalyás ízlésének nem felelt meg az Argenis választékos stílusa, nem nyerte el tetszésüket a római stóla. Nem szerették a Latiumban fogant szépséget. A könyokészitó szemében kész gyalázat, hogy mennyit költött a kötet díszitésére és csinositására, s mert nem talál viszonteladót, akitöl visszakapná, ő is a lányon tölti ki dühét. Már a bors és tömjén fenyegette. ${ }^{25}$ Tógáját sós halnak, köpenyét olajbogyónak szánták volna, ha nem folyamodott volna segítségért Marcassushoz, pedig nem volt valami nagyszerü férfi, sem fennkölt elme, sem nagy tudós. Egy plebejus és nem nemes író kedveltette meg a tudósok népével. Hogy ez milyen nevetséges! A legnagyobbak csak akkor fedezték fel az Argenist, amikor a balgák és együgyüek között aratott sikert. Vannak, akik úgy gondolják, tekintélyes és nagyszerü emberek, pedig olykor csak kicsinyes és ostoba kártevők. Ha lehúznád róluk elismertségük maskaráját, s úgy néznéd őket, emberszámba sem vennéd, vagy legföljebb hitvány embernek gondolnád az ilyeneket.

FURBINUS OPPEDIUS: Veled, Aloisia, nem bánt el ennyire - vetette közbe Oppedius - a bolond sors kénye, hisz téged dicséret nélkül hagytak a tehetetlen bolondok, s nagyszerü és kiemelkedő elmék magasztaltak. Söt olyanok is akadnak, akik lelkük mélyén kedvelnek, s mégis ócsárolnak. Magában még Tubero is elismer, Tubero, ez a minden hájjal megkent semmirekellő, aki tehetségét derék emberek és saját híre rovására kamatoztatja, és hasznot húz az istenek haragjából. Mások előtt nyíltan nem dicsér, tudomást sem vesz rólad. Elismer, de mondani rosszat mond rólad: gaz színlelő. Nem is maradt el büntetése.

MERCURIUS: Az ég haragja szent villámmal sújtott hazug és álnok fejére. mondta Mercurius. A Múzsák bosszúja feledésbe meritette e semmirekelló széltolót. Ott voltam Tubero születésénél - tette hozzá - Lavernával és Cotyttóval együtt, s ott ujjongtam bünhődésekor, saját kezüleg pofoztam fel.

FURBINUS OPPEDIUS: Kétségkívül nagy emberek, fennkölt lelkek halmozták el dicséretükkel - jegyezte meg Oppedius - mihelyt meglátták - és tönkrementek.

${ }^{24}$ Henri de Forbin-Meynier, Oppède bárója (1620-1671), politikus, politikai vitáiról ismert személyiség.

25 Tudniillik az, hogy csomagolópapírnak használják. 
MERCURIUS: Jure fit, reponit Mercurius, ut qui auro, non meritis, emerunt dignitates, id solum plurimi faciant quod auro venit, non quod ingenio. Ne quidem, paucos si exceperis magno e numero, primora labra Pegaseio latici admoverunt. Igitur probro sibi verti putant, quae laudes conferuntur in litteratos. Velles amarent Parnassum, e cujus vident arce cudi tela, quibus petantur ut ferae bestiae?

BOCCACIUS: Erant in Neapolitano Praetorio, meo tempore, reponit Boccacius, tres excetrae: Romulus, Elpinus, Valens, vaferrimi conflandis fraudibus et calumniis triumviri. Romulus cohortem duxerat, lepusculo timidior, cerva fugacior. Elpinus sacerdotem induerat: pessimum nebulonem non exuerat. At Valens, aetate provectior, in re augenda per fas et nefas totus erat. Astutam vapido sub pectore servabat vulpeculam; dulce de labris loquebatur, corde vivebat noxio. Accidit, volentibus Diis, calumniatorem insurgere in me nescio quem de lutulenta plebecula, egenum, mente captum, effrontem, Satyrum. Me insimulat criminis, me rerum repetundarum, Mercuri! me peculatus, o Musae! me! Indignabantur boni, gratulabantur sibi tres hi laverniones. Exsultabant prurienti amentia. Celebritatem nominis sperabant sibi, qualem qui Ephesinum Dianae templum subjectis flammis corrupit, qualem qui Vestalem vivam defodit insontem. Boni concupiscunt sibi gloriam, mali famam. Dire minitabantur. Dicebant sancti et probi cognitores e re sua esse me male haberi, et ignominia Boccacium mergi vel immerentem. Urgebant calumniatorem adhiberet accusationi acta, ut loquuntur, produceret testimonia, subornaret testes, acta confingeret. Volebant non veritati opem adesse, sed innocentiae deesse, veritatem opprimi, obrui innocentem.

ROMULUS: Abeat hic in malam crucem nugator! dicebat Romulus. Ausus est, quem voluit nostrum, pediculosis illis fabulis, quas misit in lucem, contaminare. Mihi quidem librorum hi scriptores odio sunt. Nam pilum mittere, ferro pugnare, hostem ferire didici, non legere; fortiter facere, non sapienter loqui. Omnia non emerim Musarum dona teruncio. 
MERCURIUS: Mégpedig joggal - vágja rá Mercurius -, mert aki pénzen s nem érdemmel szerzi tisztségeit, maga is azt tartja a legtöbbre, amiért pénzzel fizet, s nem a tehetség az ára. Rengetegen vannak, s csekély kivétellel Pegasus forrásvizét még csak ajkuk hegye sem illette. Így aztán épp azt vélik gyalázatnak, ami a müveltekre nézve dicsöséget hoz. S te még elvárnád tôlük, hogy rajongjanak a Parnasszusért, míg ormán kalapálják a hozzájuk hasonló dúvadakra váró villámokat? BOCCACIUS: Az én időmben volt a nápolyi törvényszéken - füzi hozzá Boccacius - három álnok kígyó: Romulus, Elpinus és Valens, mind triumvirek, de ravasz csalók és rágalmazók. A nyúlnál félénkebb és a szarvasnál könnyebben riadó Romulus egy katonai csapatot vezetett. Elpinus papi talárt öltött, de elvetemült hitványságából nem tudott kibújni. A már idősebb Valens meg - törvényes vagy törvénytelen úton - kizárólag vagyona gyarapításával törődött. Romlott szíve mélyén mindig is egy ravasz róka lakozott: mézesmázosan beszélt, de szíve gonosz volt. Az istenek akarata úgy hozta, hogy egyszer a mocskos aljanépból rám támadott egy rágalmazó, valami Satyrus, koldusszegény, elmeháborodott és orcátlan. Hamisan megvádolt, engem, Mercurius, vesztegetéssel vádolt, ó, Múzsák, engem sikkasztással! Minden derék ember dühöngött, e három Lavernavédenc meg majd elalélt a boldogságtól. Csak úgy tobzódtak a tébolyult kéjben. Azt remélték, végre felkapja nevüket a hír, valahogy úgy, mint azét, aki fáklyát vetett az ephesusi Diána-templomra vagy élve temetett el egy ártatlan Vestaszüzet. A jók pártjának célja a dicsóség, a rosszaké a hírnév volt. Vadul fenyegetőztek. A szent és derék bírák egyre hajtogatták, milyen fontos, hogy meglakoljak, hogy akármennyire nem érdemli, Boccaciust maga alá temesse a gyalázat. Tüzelték a rágalmazót, vádjához füzzön vádiratot - ók így nevezték, szerezzen bizonyítékokat, béreljen fel tanúkat, hamisitson okmányokat. Célul nem azt tüzték ki, hogy az igazságnak legyen, hanem hogy az ártatlanságnak ne legyen támogatója, hogy az igazság maradjon alul, és az ártatlanság szenvedjen vereséget.

\section{BOCCACIUS FELIDÉZI ROMULUS, ELPINUS ÉS VALENS BESZÉLGETÉSÉT}

ROMULUS: Pokolba a semmirekellövel! - mondogatta Romulus. Kiadta a tetves novelláit, és mindannyiunkat beszennyezett bennük, akit csak akart. Én úgy utálom az ilyen 'könyvírókat'. Az én kenyerem a dárdavetés, a kardvívás, az ellenség aprítása, nem az olvasás - a bátor cselekvés, nem a bölcs beszéd. Egy garast sem adnék akár a Múzsák minden ajándékáért. 
ELPINUS: Nam qui doctrina vigent, grunniebat Elpinus, nos flocci non faciunt: nimirum pretium in nobis nostrum inveniri debere contendunt. Auro nos perduxerunt Regis diplomata, qui plumbei eramus, aut ahenei. Aureos ideo stulti e plebe credunt: eruditi, malum! aheneos vident esse aut plumbeos; et irrident. Simulata pietate, affecto ire ad gloriam. Fallaci vultum larva improbum tegi. Stupet et veneratur jejuna plebecula, ac si jam viverem cum Jove. Pestes hominum, eruditi perspectam habent in intimis fibris mentem; contaminatam sceleratis cupiditatibus vident et oderunt. Pereant hi lynces sua cum perspicacitate! Malo noctuam Minervae mihi, quam Minervam.

VALENS: Erumpebat Valens in cachinnos: Non ita odi litteras ac $t u$, dicebat. Nam fuit mihi non ineruditus pater. Qua valebat gratia, derivavit in domum meam quicquid habet ornamenti et decoris. Sed supina superbiunt interdum contumacia viri docti. Quod velis nolunt; quod nolis volunt. Cui non doleat? Haud libenter ego tulerim. Audivi qui, orando causas, captiosis dictorum praestigiis me in curuli sedentem impeteret; qui sordes ultro objiceret insultans. Sed ea malignitatem arte effutiebat, ut ne quidem hiscere auderem. Impune oblatrabat furi, quia ingeniose. Pereant ingenio suo liberius evagante, et nostro severius ulciscente! Et Rempublicam persuasum habeo, plurimum a litteris capere detrimenti. Nec sunt utiles sibi litterati, nec rei apti faciendae. Legunt, commentantur, scribunt: quid id est prae nummis? Non emerim tribus assibus trecentos Aristoteles, nec teruncio mille Petrarchas. Malim mihi auro plenam esse crumenam, quam doctrina cerebri simus. Philosophis et Oratoribus, mea sententia, antestant longe sartores, cerdones, pistores. Deturbaverim libens e civitate mea id genus otiosorum, si legislator fiam, et in tres classes distinxerim cives. Primas tenebunt sedes Magistratus, ut nos sumus; secundas Sacerdotes, ut tu es, Elpine; inferiorem locum agricolae et opifices. 
ELPINUS: Ezek a nagy tudósok - röfögte Elpinus - minket még csak semmibe se vesznek. Persze erősködnek, hogy értékünknek bennünk magunkban kell lennie. Lehettünk bár ólomból vagy rézböl, minket a királyi diplomák aranyba vontak. A pórnép ostobái el is hiszik, hogy aranyból vagyunk, de a müvelt emberek - az ördögbe - pontosan látják, hogy rézből vagy ólomból, és jót mulatnak rajtunk. Ambicióm, hogy úgy is dicsőségre jussak, ha csak szinlelem a tisztességet. Hazug maszkot tettem gonosz képemre. Az éhező pórnép úgy bámul és tisztel, mintha máris Jupiter oldalán élnék. Az emberiség e mételye, a müvelt emberek átlátják, hogy lelkem legmélyén ez a szándékom, tudják és undorodnak töle, hogy aljas vágyak mocskolnak be. Hogy pusztulnának e hiúzok az éles szemükkel együtt! Ami engem illet, inkább Minerva baglya kell, mint Minerva.

VALENS: Erre Valensből tört ki a röhögés. - Én nem utálom annyira az irodalmat, mint te. - mondta. Az én apám nem volt múveletlen. Ami kegy és megbecsülés csak tudott, át is háramlott családomra meglehetös közkedveltségéböl. Csakhogy néha a tudós emberböl is elóbújik a dölyf: az istennek sem akarják, amit te akarsz, csak azt, amit te nem. És persze hogy rosszul esik az embernek. Én sem ugráltam örömömben, hogy el kellett türnöm. Hallottam egyszer valakit, aki perbeszédében szemfényvesztó okoskodásával megtámadott, amikor én ültem a bírói székben, magától hányta rám a mocskot. De olyan jó stílusban fröcsögött rám rosszindulata, hogy meg sem mertem mukkanni. Büntetlenül ugathatta meg a tolvajt, mert szellemesen tette. Pusztuljanak, mert szellemük szabadabban szárnyal, ám a miénk ezért kegyetlen bosszút áll. A köztársaságot is meggyőztem róla, hogy az irodalom nagy bajba keveri. Az írástudók sem maguknak nem hajtanak hasznot, sem semmi mást elintézni nem képesek. Olvasnak, kommentálnak, irnak: miért is érne ez többet a pénznél? Én három garast se adnék háromszáz Arisztotelészért, s egy fillért se ezer Petrarcáért. Inkább az erszényem legyen teli arannyal, mintsem hogy a tudományban legyek elismert. Szerintem akár egy foltozó szabó, akár egy kézmüves, akár egy halász is többet ér egy filozófusnál vagy szónoknál. Ha én hoznám a törvényeket, szíves örömest kiüzném a városomból az ingyenélők egész fajtáját, s a polgárokat három osztályba sorolnám. Az elsô hely a miénk lesz, tisztviselőké, a második a papoké, aki te is vagy, Elpinus, a legalsó a föld-és kézmüveseké. 
ELPINUS: Ineptum istud, respondebat Elpinus. Ineptum te legislatorem! Nam primo sunt in loco Sacerdotes. Quis dubitet, nisi amens et impius?

VALENS: Accepi, reponebat Valens, jureconsultum, nescio quem, magni nominis, nam nimis curiosus nunquam fui, dicere Magistratus omnes Themidis esse Sacerdotes. Ergo qui sunt et Magistratus et Sacerdotes, ut tu es, Elpine, praestant Sacerdotibus. Sed oriatur nulla inter nos rixa, nulla contentio, nulla animi laesio. De Boccacio fieri quicquid jusseris, et id ego fieri jubeo. Innocens scilicet erit quem oderimus? Meo damnare calculo, vel frugi, vel innocentem, vel sanctum certum est. Et blandiens nummi refulget spes?

Tros Rutulusve fuat, nullo discrimine habebo, ${ }^{26}$

ut quidam inquit poeta magnus, puto, Donatus. Nam alium non memini me legere. Dein id erit quod judicaverimus, non quod vere est. Res judicata facit de albo nigrum, de nigro album. O coeleste, per Ditem et Plutum, numina mea, prudentiae juris effatum! Nam quid commodius et opportunius? O utile nobis, non ita sapientibus, ex arcana sapientia oraculum!

BOCCACIUS: Quid plura, sancti Manes? Regi Roberto (cui non dictus Robertus Rex?) re intellecta, non potuit continere se placidissimus Princeps, quin sacro conciperet iram pectore dignam se optimo, maximo, dignam Deo optimo maximo. Nec mora: verbis castigat amaris excitos ad se. Dein sublimi e sede, quam dehonestabant, agit fulminatrici manu praecipites: abdicat magistratu, quem incestabant. Romulum Thrasonem, ne fabulae quid deesset ridiculi, et tamen duri, lixis exercitus, quem coegerat in Insubres, praefecit moderatorem, et calonibus. Nosocomio incurabilium abdit Elpinum; Valentem vero avarum et praedae inhiantem Judaeo Manassi, Portorii apud Calabros redemptori, sufficit.

${ }^{26}$ Verg. Aen. 10, 108. 
ELPINUS: Nem úgy van az! - felelt Elpinus. Nem vagy valami jó törvényhozó. Az első hely természetesen a papoké. Csak egy örült vagy istentagadó gondolhatja másképp.

VALENS: Erre Valens: Én úgy hallottam valami jó nevú jogtudortól (mert engem azért annyira nem evett a kíváncsiság), hogy minden tisztviseló Themis papja. Ebböl következik, hogy aki egyszerre tisztviselö és pap, amint te is, Elpinus, az elóbbrevaló egy papnál. De ezen ne veszekedjünk, vitázzunk, ne legyen belöle sértôdés. Boccacius ügyében én is biztosan azt teszem, amit te tennél. Mert lehet-e ártatlan, akit mindketten gyülölünk? Az én szavazatom legalábbis biztos, tôlem lehet derék, ártatlan vagy akár kész szent is. Hát ha még a pénz reménye is rám mosolyog...

\section{Trósz-e avagy rutulus, mindegy lesz előttem ezentúl, ${ }^{27}$}

ahogyan egy nagy költő is mondta, mégpedig szerintem Donatus, mert nem rémlik, hogy olvastam volna mást. Aztán meg úgy lesz, ahogyan itélünk, nem pedig úgy, ahogyan igazságos lenne. Ha egy ügyben egyszer itélünk, az fehérből feketét és a feketéból fehéret csinál. Isteneimre, Disre és Plutóra, hogy milyen mennyei itéletet hoztunk! Lehet-e bármi hasznosabb vagy elönyösebb? Ó, te na nem a bölcsek, hanem a mi - hasznunkra szolgáló, titkos bölcsesség adta jósszó!

\section{ROMULUS, ELPINUS ÉS VALENS BESZÉLGETÉSÉNEK VÉGE}

BOCCACIUS: Minek folytassam, szent Szellemek? Róbert király - ki ne hallott volna már Róbert királyról - tudomást szerzett az esetről, s a legszelídebb fejedelem alig tudta megállni, hogy szent szíve ne lobbanjon legnagyobb és legjóságosabb mivoltához méltó, a legnagyobb és legjóságosabb istenhez méltó haragra. Késedelem nélkül szine elé rendeli és dühös szavakkal dorgálja őket, majd magas posztjukról, amelyet megcsúfoltak, mennykövet szóró karja lehajította őket, megfosztja tisztségüktöl, amelyet beszennyeztek. De hogy, bármily lehangoló, legyen valami vidám is a történetben, Romulus Thrasót az insuberek ellen fölállított hadsereg markotányosai és táborszolgái parancsnokává tette, Elpinust a gyógyíthatatlanok kórházába rekkentette, a kapzsi és zsákmányra éhes Valenst pedig a zsidó Manassé, calabriai révvámbérlő posztjára tette.

27 Lakatos István fordítása. 
ROBERTUS REX: O infelicitatem temporum meorum! ingemebat coelo dignus Princeps. Boni et honesti vocabantur ad Judices: in lupos incidebant et leones. Discant hoc reliqui exemplo justitiam! Suos discant mores in sacraria Justitiae non inducere. Dignum quidem fortitudine, qua se jactat amens Romulus, munus cepit. Lixis et calonibus ducem praefeci. In impedimentis exercitus, impedimentum ipse, Martem aget; insultabit Alexandro. Elpinum detrusi in Nosocomium incurabilium: nam quis aegrum ira, avaritia, superbia curarit unquam belluae animum vel homo vel Deus? Nulla mansuescunt arte his in verbis animarum morbi. Sed mortuo suffeci Judaeo Valentem. Conquerentur, scio, Calabri Judaeum decessisse Judaeo, forte et Arabem e Mahometis secta missum conquerentur: videbimus. Sic acta est fabula, quibus ferocire, nocere, pessumdare ludus erat.

FURBINUS OPPEDIUS: Belle, belle! exclamat Oppedius. Nam is non fui de quo quicquam litterati queri possint agitasse unquam animo consilii, quod Musis injuriosum videretur.

MERCURIUS: Nomen igitur tuum et decus, infit Mercurius, commendabunt litteratae immortalitati. Sempiternum per aevum volitabis vivus, ut gloriabatur de se moriens Ennius, per ora virum. Sed me vocant jussa Jovis. Valete, cari Manes. Fruimini laeti et securo in otio, Elysii campi deliciis, et vobis fruimini alter altero. Vetant quae habeo in mandatis esse vobiscum diutius. Tunc celeri raptus alarum remigio evolavit.

ALOISIA: Superest vero mihi, VIR SUMME, ut paucis de me dicam, quo sim notior tibi, quam esse possum, si non dixerim. Vivebam ante annos centum in Hispania, Toleti nata. Ingenio, eruditione, forma praestiti, et omnibus excellui virtutum dotibus, quae ingenuas decent. Non in abjecta animi demissione, non in sordida rei familiaris cura, non in vili nugarum studio virtutem mihi positam habebam: 
RÓBERT KIRÁLY BESZÉDE: „Hogy én milyen szerencsétlen korban élek!” sóhajtotta e mennybe menendő fejedelem. „Derekakat és jókat fognak perbe, farkasok és oroszlánok közé hullanak. Tanuljon mindenki más igazságosságot e példából! Tanulják meg, hogy ilyen erkölcsöket Justitia szentélyének még csak a közelébe se engedjenek. A Romulusnak adott poszt éppen megfelel bátorságának, amellyel hencegett: a markotányosok és táborinasok parancsnokává tettem. Ő is csak teher, a hadsereg málhái közt küzd, egy Nagy Sándort is megszégyenít. Elpinust a gyógyíthatatlanok kórházába tettem le, hisz egy beteg állati lelket ki gyógyíthatna ki a haragból, dölyfböl, legyen akár ember, akár isten. A lelki betegségek e szavakra nem szelídülnek. Valenst pedig egy elhunyt zsidó posztjára helyeztem. Tudom, panaszkodnak már Calabriában, hogy zsidó helyébe zsidó került, de tán panaszkodnának akkor is, ha egy arabot küldtem volna Mohamed felekezetéból - majd meglátjuk." - Itt ér véget a történetem azokról, akiknek vadság, ártás és pusztítás csak játék volt.

FURBINUS OPPEDIUS: Szép volt, szép volt! - kiált fel Oppedius. - Nekem aztán egy írástudó sem tehet szemrehányást, hogy valaha is a Múzsákkal szemben igazságtalan tervet forgattam volna a fejemben.

MERCURIUS: Úgy hát dicső nevednek halhatatlanságot szereznek. - szólt Mercurius. Örök idókig élsz és szállsz hát szájról szájra - mint Ennius büszkén mondta magáról halála elôtt. Na de engem most Jupiter parancsa szólit. Ég veletek, kedves Szellemek! Élvezzétek gondtalan nyugalmatokban boldogan az Elíziumi mezők gyönyöreit, és élvezzétek egymás társaságát. Megbizatásom nem engedi, hogy tovább időzzem veletek. - Azzal szárnyai gyors evezőjére kapott és elrepült.

\section{AZ ALVILÁGI JELENET VÉGE}

ALOISIA: Már csak az van hátra, nagyszerü férfi, hogy szóljak néhány szót magamról, hogy jobban ismerj, mint ismernél, ha semmit sem mondanék. Hispániában éltem száz évvel ezelőtt, Toledóban születtem. Tehetségem, képzettségem, szépségem párját ritkította, s az erények minden, nemes hölgyhöz illő nemében kiemelkedtem. Tehetségemet sem lankasztó csüggedésre, sem a családi vagyon szennyes gondjára, sem holmi szórakozásban való értéktelen elmerülésre nem vesztegettem. 
liberalibus navare operam disciplinis, scriptis pulchram mihi et aeternam parere famam, ad summam sapientiam niti, non ad summas contendere opes, id demum optimum putabam, laudabile praedicabam: quod tamen foeminae pleraeque omnes per ignaviam negligunt; homines multi, per socordiam stultam et furentem, contemnunt. Quamobrem veri amans libere malos insectabar; quae sentirem de flagitiosis et impuratis ultro intonabam. Velut quadam in curuli sedens sella, morum Censuram exercebam, plaudente e coelo Pudicitia. Me suspiciebant omnes, et ob os ora obvertebant sua. Nobilium imprimis foeminarum spurcis infensa libidinibus infremebam: quo injecto saltem pudore ad meliorem revocarem frugem, nihil non agebam: pati non poteram specie praelucentes, nobilitate commendabiles, brevis gaudii aut spe aut gustu, velut emotas mente, ipsas in ludibria se vertere. Dicebam, ut Virtuti honestum et gloriosum est nudam sisti ob oculos mortalium, sic Vitiis esse ignominiosum. Quae meretricie viverent, ideo volui e fornicibus suis, in quibus latebant, in scenam humanae vitae nudas educere, quae essent documento impune non peccari, mulieres quasdam superbi nominis et oris, et alto cretas sanguine. Nam, quas Tulliam, Octaviam, Semproniam, Eleonoram, Isabellam voco, eae fuerunt Ducum, Marchionum, Comitum aut uxores aut sorores. De his enarro nihil quod vere non factum sit, et ut eram a mendacio et ab omni dissimulationis et simulationis specie alienissima, liberiori omnia sermone exsecuta sum, qui solus conveniebat.

Satyram Sotadicam inscripsi opus, quod Colloquiis sex complexa sum, et infra mensem absolvi. De Sotade nihil est quod dicam. Rerum amatoriarum scriptorem fuisse liberrimum, neminem fugit. Sed puellam ad scribendum his de rebus animum appulisse, post Elephantidem et Philaenim, nihil mirum videri debet. Fuerunt et aliae hoc scriptionis genere celebres. Et sane aptiores sunt foeminae his rebus depingendis, si quae sint cordatae, si quae non fatuae procacitatis. 
A legjobbnak gondoltam, s állítottam is, hogy dicséretes: hogy tanulmányozzam a szabad müvészeteket, hogy írásaimmal szép és örök hírnevet szerezzek, hogy törekedjem a legfőbb bölcsességre, viszont ne törjek nagy vagyonra - egyszóval célom csupa olyasmi volt, amit erélytelenségében majd' minden más nő elhanyagol, és sok ember néz le bárgyú és őrült esztelenségében. Így aztán én, az igazság szerelmese, bátran üldöztem a gonoszokat, s önszántamból fennhangon hirdettem, amit a becstelenekről és gyalázatosokról gondoltam. Mint valami hivatali székből gyakoroltam erkölcsi cenzúrát, Pudicitia tapsolt hozzá az égből. Mindenki feltekintett rám, fürkészték tekintetemet. Elsősorban a nemes hölgyek ocsmány vágyai ellen acsarogtam, mindent megtettem, hogy legalább a szemérem leplét rájuk vessem, s megnyerjem őket a jobb életnek. Képtelen voltam elviselni, hogy e ragyogó külsejü, nemesi mivoltukban jobb sorsra érdemes nők a nyúlfarknyi öröm ízlelésének reményében önmagukból kivetkőzve kéjelgésnek adják át magukat. Hangoztattam, hogy amint tisztes és dicső az erény kedvéért mezítelenül mutatkozniuk mások szeme előtt, éppoly gyalázatos, ha ezt a bün szándékával teszik. Ezért akartam e dölyfös nevű és ábrázatú, előkelő származásuktól elbizakodott, de kéjnőkként élő asszonyok némelyikét budoárjaikból, ahová visszavonultak, mezítelenül az emberi élet színpadára állítani, legyenek élő példák arra, hogy nem lehet büntetlenül vétkezni. Mert a nők, akiket Tulliának, Octaviának, Semproniának, Eleonorának, Isabellának nevezek, hercegek, őrgrófok, grófok hitvesei és nővérei. Elbeszélésemben semmi sincs, ami meg ne történt volna, s mert a hazugság, a tettetés és leplezés minden neme a lehető legtávolabb állt tőlem, az egészet meglehetősen szókimondóan beszéltem el, lévén, hogy mindehhez csak ez a stílus illett.

Munkámnak a Szótadeus szatíra címet adtam, mert hat Beszélgetést foglal magában, és egy hónapon belül elkészültem vele. Szótadészről nem kell beszélnem, úgyis mindenki tudja, hogy szókimondó szerelmi történetek szerzője volt. Abban sincs semmi csodálatos egy Elephantis és Philaenis után, hogy nő létemre ilyen témák feldolgozásába fogok. Alkottak ebben a müfajban más nők is, s a nők, amennyiben eszesek s nem orcátlan bolondok, messze alkalmasabbak e témák leírására. 
Libidinum ipsae sunt campus in quo nascuntur omnes, in quo efflorescunt, in quo vigent, oriuntur et occidunt. Hispanice scripsi: vir doctus Joannes Meursius, Lugdunensis apud Batavos Academiae clarissimum lumen, Latinitate donavit adolescens; etiam adjecit, quae mihi sane non venerant in mentem. Sed liber periit meus Hispanice scriptus, Meursii superest commentatio, non infelicis ingenii, non proletariae eruditionis partus, quae nec fastidium legenti creet, nec stomachum moveat Sapienti. Attico sale condita omnia. Invideri tam salsa, tam lepida, tam etiam utilia bene vivendi praecepta huic aetati tuae bonis litteris amicae turpe esset, et studiosis arduae sapientiae ingeniis durum. Quis aegre molesteque non ferret? Bonos utique mores laudet Tullius; Philosophus doceat Plato: melius sane suadebunt Publius Syrus, Laberiusque Mimi. Ferit mentem et movet qui miscet utile dulci; a qua plerumque aberrat laude verbosus Orator, strigosus Philosophus. Medicamentis vires addit, dum horrorem et odium adimit, qui in bellaria format solers Medicus. Haec mea fuit cogitatio. Omne mihi visa sum punctum tulisse, quae ingeniose, quae facete utile dulci miscuissem. Dura tamen amori silex fui: pectus nullo fixi telo. Inaccessa libidini malae, sanctam constanter duxi vitam. Severiori virtuti assidua haesi comes. Mores laudarunt boni, reveriti sunt mali. Et his et illis eram acceptissima. Ut Regibus, et principibus in Republica viris, sic et plebi placui miranti. Me et litterati coluerunt, litterarum, ut dicebant, bono natam. Cave de pura et proba, VIR BONE ET SANCTE, hac judices ex libertate loquendi quae sentirem. Foedas depinxi rerum species, non amavi. Depinxi, quia odio habebam. Inique feceris, si velis has, adversus Aloisiam tuam, pictas tabulas testimonia esse, et Tulliam, Octaviam, testes. Humanius age. Famam consule; gloriam consule nominis mei, quae nulla obsolevit annorum injuria. Uni judicium accommoda. Vale. 
Valamennyien terepét jelentik a vágyaknak, mert ebben születnek, virágoznak és teljesednek ki, születnek s halnak meg. Spanyolul írtam, s a tudós, a Leideni Akadémia állócsillaga, Johannes Meursius fordította le fiatalkorában, s olyasmivel is megtoldotta, ami nekem aligha jutott volna eszembe. Ám könyvem spanyol eredetijének nyoma veszett, csak a nem mindennapi tehetségű $s$ nem közönséges képzettségü Meursius szövege van meg, mely olvasójában sem kelt undort és a tudóst sem bosszantja halálra. Attikai só ízesít benne mindent: szépirodalom iránt olyannyira elkötelezett korodban rút, s a bölcsesség legfelső grádicsain álló szellemek számára is terhes lenne, ha e szellemes, ízléses s ráadásul hasznos életvezetési tanácsokra rossz szemmel néznének. Elviselése is bosszantó és kellemetlen lenne. Bárhogy is magasztalja Tullius, s tanítja a filozófus Platón a jó erkölcsöket, messze jobban nyernek meg nekik Publilius Syrus és Laberius mimusai. A szívbe hatol, azt mozgatja meg, aki a kellemest a hasznossal elegyíti, s a szavakban tobzódó szónok, s a szikár filozófus közelébe sem jut ennek a dicsőségnek. A ravasz orvos egyszerre fokozza orvossága erejét, s szüntet meg iránta minden félelmet és utálatot, ha csemegének álcázza. Engem is ez az elv vezérelt, s úgy tünik, osztatlan tetszést is arattam azzal, hogy oly kifinomultan és szellemesen vegyítettem a hasznosat az édessel. Én magam kemény kőszikla voltam a szerelemmel szemben, egy szívbe sem lőttem nyilát. Hozzám sem férhetett bünös vágy, szent életvitelemben állhatatos voltam. A szigorú erkölcs kitartó társául szegődtem. A derekak dicsérték, s a rosszak is tiszteletben tartották. Ezek is, azok is a legmesszebbmenőkig elfogadtak. A köznép éppúgy kedvelt és csodált, mint a királyok és az állam vezetői. A müveltek is elfogadtak, mert - mint mondták - az irodalom javára születtem. Derék és szent férfiú, ne e szabadszájúság alapján ítéld meg, hogy tiszta és tisztességes asszony létemre mit gondolok. Én csak lefestettem a jelenségek e rút fajtáit, de hívük nem voltam. Azért festettem le őket, mert utáltam. Igazságtalanul tennéd, ha e képeket híved, Aloisia elleni tanúságnak, Tulliát és Octaviát meg tanúnak vennéd. Légy emberséges, tekintsd hírnevemet, tekintsd nevem dicsőségét, amelyet a hosszú évek során semmiféle igazságtalanság nem feketíthetett be! Ítéleted szabd kizárólag személyemre! Isten veled! 